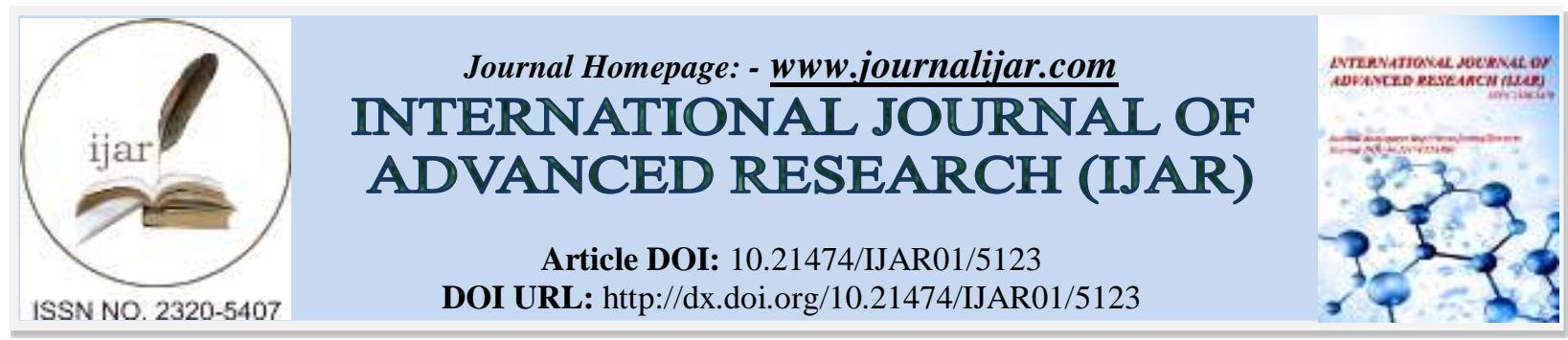

RESEARCH ARTICLE

\title{
ESTIMATING AMOUNT OF BIOMASS LOSS AND CARBON RELEASED TO THE ATMOSPHERE AS A RESULT OF HABITAT CONVERSION OF EASTERN SELOUS - NIASSA TFCA.
}

Adili Y. Zella, Josephat Saria and Yohana Lawi.

1. Department of Economic Studies, The Mwalimu Nyerere Memorial Academy (MNMA)-Zanzibar, P.O Box 307, Zanzibar, Tanzania.

2. Department of Environmental Studies, Faculty of Science, Technology and Environmental Studies, Open University of Tanzania, P.O Box 23409, Dares Salaam, Tanzania.

\section{Manuscript Info}

Manuscript History

Received: 10 June 2017

Final Accepted: 12 July 2017

Published: August 2017

Key words:-

Habitat conversion, Climate change mitigation and adaptation, Biomass, Carbon.

\section{Abstract}

Countries' authorities that managing unfenced protected areas (PAs) as an effort to maintain biodiversity and ecosystem services, airs challenges of climate change and variability which disturb habitat and force wildlife to move to other unprotected areas for adaptation purposes. This scenario necessited the inclusion of those adapted areas into PAs network and recategorise the abandoned areas in the PAs. The unprotected areas include wildlife corridors which connects two or more PAs within the country or transboundary areas famously known as transfrontier conservation areas (TFCAs). However, corridor dwellers especially in developing countries unsustainably utilizing corridor fauna and flora for their livelihoods. This paper explains the less known amount of biomass loss and carbon released to the atmosphere as result of habitat conversion of eastern Selous - Niassa wildlife corridor which connecting the two PAs of Tanzania and Mozambique. Specifically, the study estimates amount of biomass loss, amount of carbon released to the atmosphere and amount of conservation profit disposed as a result of habitat conversion from 1986 to 2016. Existing data on spatial and temporal changes in land use and land cover of eastern Selous - Niassa TFCA from 1986 - 2016 was analysed to get intended results. The results reveled that, an average amount of 163732.8 tons of biomass (above ground + below ground + deadwood) loss annually from 1986 to 2016. Consequently, average amount of 240176.9 tons of carbon (above ground + below ground + deadwood) released to the atmosphere annually from 1986 to 2016 equivalent to US\$ 960707.5 per annum if REDD+ was implemented. The amount of conservation profit of the area seems to offset amount of benefit received by corridor dwellers from their destructive activities if adopted REDD+ strategies. The foreseeable future necessitates inclusion of the area into core PAs, however, there is a cost which the government must incur in order to safeguard the adaptation scenarios of wildlife suffered from climate change and variability in core PAs 


\section{Introduction:-}

\subsection{Background information:-}

Habitat loss and fragmentation, pollution, overexploitation, accelerated climate change and erupted harmful invasive alien species threaten the biodiversity and ecosystem services on which flora and fauna livelihoods rely. Increased atmospheric carbon dioxide, increased land and ocean temperatures, changes in precipitation, and rise in sea level affects both natural systems and human welfare (World Bank, 2010; and Strange et al., 2011). Already global warming and climate changes have observed impacts on natural ecosystems and species (World Bank, 2010; Ara_ujo et al., 2011; and Fordham et al., 2013). Sub-Saharan Africa's ecosystems seem to be more vulnerable as climate changes cause extinctions of some species and affect their distribution, behavior, and reproduction of species, patterns and migrations.

Climate change is likely to accelerate the ongoing impoverishment of global biodiversity and degradation of ecosystems caused by unsustainable use of natural capital and other environmental stresses. Such degradation and disturbance in terrestrial and aquatic ecosystems generate niches that can be exploited by invasive alien species, leading to further ecosystem change and degradation. Global climate change can and has been caused by natural factors in the past, including shifts in the earth's orbit; circulation of the oceans; volcanic activity, or intensity of the sun. Currently, human anthropogenic activities are changing the climate through increasing the amount of greenhouse gases like carbon dioxide in the atmosphere. Increases in carbon emissions come from burning fossil fuels like oil and gas, deforestation, developing land for farms, cities, and roads.

Considering the impacts of climate change insisted the need for new conservation areas to fill connectivity gap between protected areas (PAs) through habitat corridors so as to enable species migration with their climatic niche (Williams et al., 2005; Heller and Zavaleta, 2009). Connectivity of PAs through corridors advocacy adaptation of reserved fauna and flora under climate change. PAs are natural homes for the conservation of indigenous species that are resistant to pests, diseases and pathogens, environmental stresses and nutrient loss. PAs are also potentially beneficial as carbon sinks and for environmental conservation. The protection of corridor biodiversity relies on the ability to assess hot spots, quantify and predict spatial and temporal trends of key species maintain a natural disturbance regime and limit harmful human activities (Stohlgren et al., 1999). However, biological effectiveness of corridors is questionable by various scientists, arguing that established strategies focusing on PA aggregation and representativeness are more robust in the face of climate change (Hodgson et al., 2009). Prioritizing new conservation areas and recategorize the abandoned PAs is a debatable new agenda; while, quantitative comparisons of the effectiveness of different PAs design strategies in retaining biodiversity over time are less documented (Pressey et al., 2007; Carroll et al., 2010). Studies have applied dynamic landscape and metapopulation models to assess the relative benefits of corridors compared with larger terrestrial PAs and spatially dynamic versus static protected areas in maintaining populations for a focal species over time (Falcy and Estades, 2007; Rayfield et al., 2008). One of the primary limitations in quantitatively assessing the effectiveness of alternative habitat configuration strategies has been the lack of suitable ecological modeling frameworks.

\subsection{Problem statement:-}

Climate is changing and that the changes are largely due to increased levels of carbon emissions into the atmosphere caused by human activities. Global climate change is continuously caused by natural factors in the past, including shifts in the earth's orbit or the circulation of the oceans, volcanic activity, or even the intensity of the sun. Currently human activities are changing the climate by increasing the amount of greenhouse gases like carbon dioxide in the atmosphere. Increases in carbon emissions come from burning fossil fuels, deforestation, developing land for farms, cities, and roads. The recommended response from society to climate change involves two sets of activities: mitigation and adaptation. Mitigation activities encompass those attempts to reduce emissions by using less energy or alternative forms of energy that produce fewer emissions of heat-trapping gases. Adaptation is the complementary component of a comprehensive response strategy to climate change and includes activities that attempt to adjust or respond to the environmental changes caused by climate change (Milad et al., 2011).

Adaptation accepts that the climate is already changing and that increased carbon dioxide levels are the new reality that we must plan for, including anticipated impacts from more severe weather (Munishi, 2010). Adaptation specifically for wildlife involves planning and taking actions that will allow wildlife to respond to this climate change with viable populations. As climate change exacerbates the threats that are already on the landscape, thus 
the need for a new strategic framework for conservation is unavoidable (Li et al., 2007). This framework needs to include new protected areas that account for species range shifts and management that addresses large-scale change across international borders.

The aforementioned circumstances necessitate the need for Tanzania and Mozambique Governments to include eastern corridor of Selous - Niassa TFCA into the PAs ecosystem network that formulate the TFCA. However, the corridor dwellers unsustainably utilize available ecological resources for their livelihoods. The utilization involves conversion of corridor habitat to other land uses. Hence, this scenario calls for urgency estimating the amount of biomass loss and carbon released to the atmosphere as a result of corridor's habitat conversion so as to plan for sustainable management strategies of the TFCA.

\subsection{Objectives:-}

\subsubsection{Main objective:-}

The main objective of this study was to estimate amount of biomass and carbon released to the atmosphere as a result of habitat conversion of eastern Selous-Niassa TFCA

\subsubsection{Specific objectives:-}

Specifically the study intends to:

(i) estimate amount of biomass loss of eastern Selous-Niassa TFCA from 1986 to 2016

(ii) estimate amount of carbon released to the atmosphere as a result of habitat conversion of eastern SelousNiassa TFCA from 1986 to 2016

(iii) estimate amount of conservation profit disposed as a result of habitat conversion of eastern Selous-Niassa TFCA from 1986 to 2016

\section{Materials And Methods:-}

\subsection{Materials:-}

\subsubsection{Description of the Study Area:-}

The study was carried out in eastern Selous-Niassa TFCA with an area of 1, 462, 560 hectares called Selous-Niassa wildlife corridor (SNWC) which extends across southern Tanzania into northern Mozambique (Figure 1). Administratively passes in Liwale, Nachingwea, Masasi, and Nanyumbu Districts. Migration of elephants, buffalos and zebras has been observed (Pesambili, 2003; Ntongani et al., 2007). Two migratory routes have been identified as follows:

(i) From Selous through Nahimba, Nakalonji, Mbondo, Kilimarondo, Matekwe and Kipindimbi proposed game reserve (GR) in Nachingwea District and then via Msanjesi, Mkumbalu, Sengenya, Nangomba and Nanyumbu in Nanyumbu District to Lukwika-Lumesule GR and then crosses Ruvuma River to the Niassa GR.

(ii) From Selous to Kiegei, Namatumu, Kilimarondo in Nachingwea then along Mbangala and Lumesule rivers to Mchenjeuka and Mitanga in the Lukwika-Lumesule GR, from where they cross the Ruvuma River to the Niassa Reserve.

These routes forms SNWC called Selous-Masasi corridor includes the Msanjesi (2,125 ha) and the LukwikaLumesule (44,420 ha) GRs in Masasi and Nanyumbu Districts respectively; wildlife management areas (WMAs) bordering Selous, Msanjesi and Lukwika-Lumesule game reserves (MAGINGO WMA, NDONDA and MCHIMALU proposed WMAs respectively) which are within Liwale, Nachingwea/Masasi and Nanyumbu Districts respectively. 


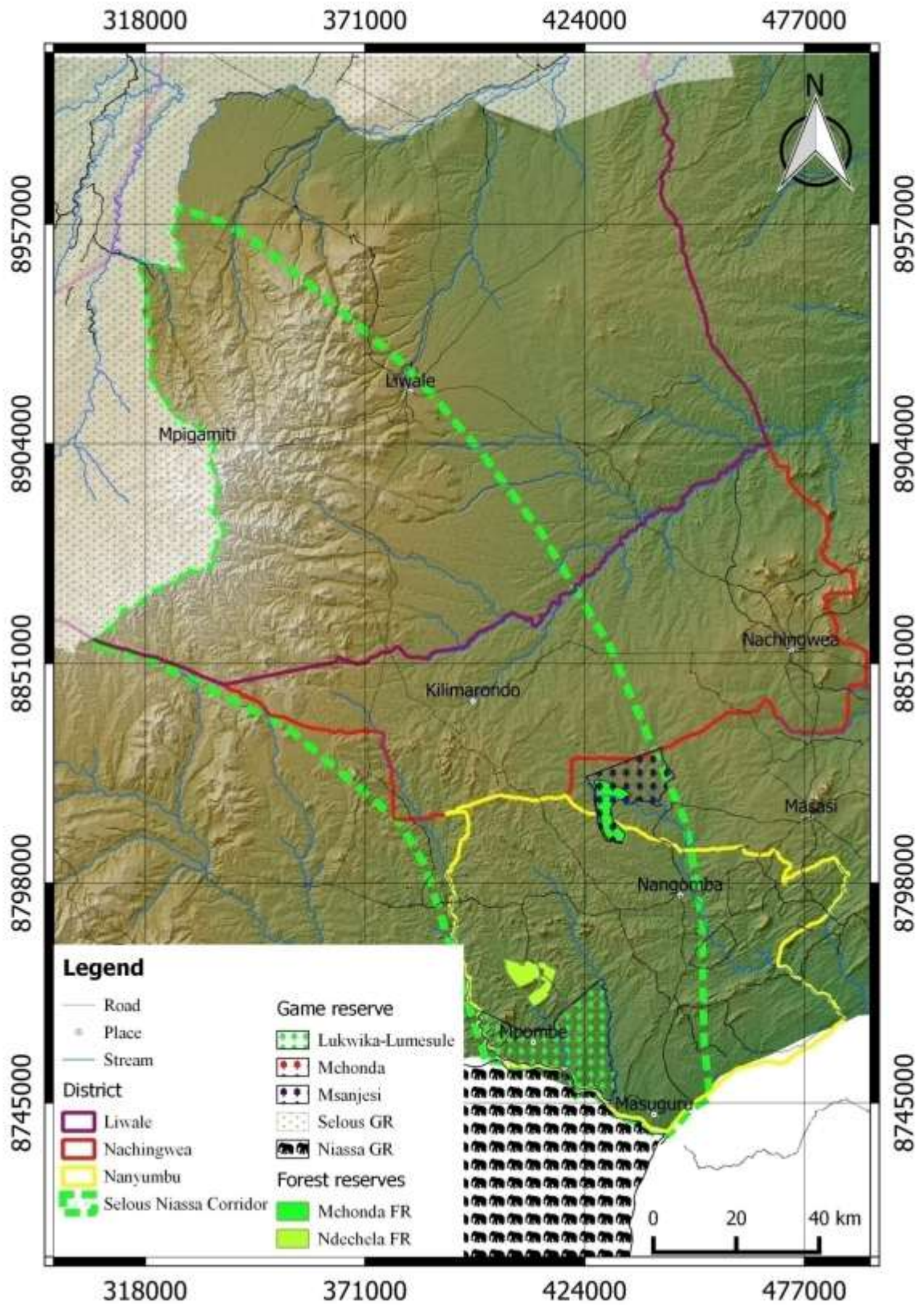

Figure 1:- The Map of the study area 


\subsection{Methods:-}

Existing data on spatial and temporal changes in land use and land cover of eastern Selous - Niassa TFCA from $1986-2016$ as shown in Tables $1,2 \& 3$.

Table 1:- Land use/cover area distribution between 1986 and 2016

\begin{tabular}{|l|l|l|l|l|l|l|l|l|}
\hline \multirow{2}{*}{ LULC } & $\mathbf{1 9 8 6}$ & $\mathbf{1 9 9 7}$ & $\mathbf{2 0 0 5}$ & $\mathbf{2 0 1 6}$ & \\
\cline { 2 - 9 } & $\mathbf{( H a )}$ & $(\boldsymbol{\%})$ & $(\mathbf{H a})$ & $(\boldsymbol{\%})$ & $\mathbf{( H a )}$ & $(\boldsymbol{\%})$ & $\mathbf{( H a )}$ & $(\boldsymbol{\%})$ \\
\hline CWD & 227731 & 15.57 & 244348 & 16.71 & 103198 & 7.06 & 89923 & 6.15 \\
\hline OWD & 402201 & 27.50 & 411211 & 28.12 & 288176 & 19.70 & 220217 & 15.06 \\
\hline BS & 433706 & 29.65 & 333399 & 22.80 & 256911 & 17.57 & 480269 & 32.84 \\
\hline GL & 394960 & 27.00 & 437621 & 29.92 & 515143 & 35.22 & 394461 & 26.97 \\
\hline WTR & 1431 & 0.10 & 790 & 0.05 & 906 & 0.06 & 646 & 0.04 \\
\hline CL & 0 & 0.00 & 31799 & 2.17 & 290602 & 19.87 & 268193 & 18.34 \\
\hline BLT & 2532 & 0.17 & 3391 & 0.23 & 7623 & 0.52 & 8851 & 0.61 \\
\hline TOTAL & $\mathbf{1 4 6 2 5 6 0}$ & $\mathbf{1 0 0}$ & $\mathbf{1 4 6 2 5 6 0}$ & $\mathbf{1 0 0}$ & $\mathbf{1 4 6 2 5 6 0}$ & $\mathbf{1 0 0}$ & $\mathbf{1 4 6 2 5 6 0}$ & $\mathbf{1 0 0}$ \\
\hline
\end{tabular}

CWD = Closed woodland, OWD = Open woodland, $\mathbf{B S}=$ Bushland, $\mathbf{G L}=$ Grassland, $\mathbf{W T R}=$ Water, BLT $=$ Built Up area, and $\mathbf{C L}=$ Cultivated land

Table 2:- Land use/cover change between 1986 and 2016

\begin{tabular}{|c|c|c|c|c|c|c|c|c|c|}
\hline \multirow{2}{*}{$\begin{array}{l}\mathbf{L} \\
\mathbf{U} \\
\mathbf{L} \\
\mathbf{C}\end{array}$} & \multicolumn{3}{|c|}{$1986-1997$} & \multicolumn{3}{|c|}{$1997-2005$} & \multicolumn{3}{|c|}{$2005-2016$} \\
\hline & $\begin{array}{l}\text { Area } \\
\text { chang } \\
\text { e (Ha) }\end{array}$ & $\begin{array}{l}\text { Percent } \\
\text { age } \\
\text { change } \\
(\%)\end{array}$ & $\begin{array}{l}\text { Annual Rate } \\
\text { of Change } \\
\text { (Ha/year) }\end{array}$ & $\begin{array}{l}\text { Area } \\
\text { chang } \\
\text { e (Ha) }\end{array}$ & $\begin{array}{l}\text { Percent } \\
\text { age } \\
\text { change } \\
(\%)\end{array}$ & $\begin{array}{l}\text { Annual Rate } \\
\text { of Change } \\
\text { (Ha/year) }\end{array}$ & $\begin{array}{l}\text { Area } \\
\text { chang } \\
\text { e (Ha) }\end{array}$ & $\begin{array}{l}\text { Percent } \\
\text { age } \\
\text { change } \\
(\%)\end{array}$ & $\begin{array}{l}\text { Annual Rate } \\
\text { of Change } \\
\text { (Ha/year) }\end{array}$ \\
\hline $\begin{array}{l}\text { C } \\
\text { W } \\
\text { D }\end{array}$ & -16617 & -1.14 & -1511 & $\begin{array}{l}14115 \\
0\end{array}$ & 9.65 & 11762 & 13275 & 0.91 & 1207 \\
\hline $\begin{array}{l}\mathbf{O} \\
\text { W } \\
\text { D }\end{array}$ & -9010 & -0.62 & -819 & $\begin{array}{l}12303 \\
5\end{array}$ & 8.41 & 10253 & 67959 & 4.65 & 6178 \\
\hline $\begin{array}{l}\text { B } \\
\text { S }\end{array}$ & $\begin{array}{l}10030 \\
6\end{array}$ & 6.86 & 9119 & 76488 & 5.23 & 6374 & $\begin{array}{l}- \\
22335 \\
7\end{array}$ & -15.27 & -20305 \\
\hline $\begin{array}{l}\mathbf{G} \\
\mathbf{L}\end{array}$ & -42661 & -2.92 & -3878 & -77522 & -5.30 & -6460 & $\begin{array}{l}12068 \\
2\end{array}$ & 8.25 & 10971 \\
\hline $\begin{array}{l}\mathbf{W} \\
\mathbf{T} \\
\mathbf{R}\end{array}$ & 641 & 0.04 & 58 & -116 & -0.01 & -10 & 260 & 0.02 & 24 \\
\hline $\begin{array}{l}\text { C } \\
\text { L }\end{array}$ & -31799 & -2.17 & -2891 & $\begin{array}{l}- \\
25880 \\
3 \\
\end{array}$ & -17.70 & -21567 & 22409 & 1.53 & 2037 \\
\hline $\begin{array}{l}\text { B } \\
\mathbf{L} \\
\text { T }\end{array}$ & -860 & -0.06 & -78 & -4232 & -0.29 & -353 & -1228 & -0.08 & -112 \\
\hline
\end{tabular}

CWD = Closed woodland, OWD = Open woodland, BS = Bushland, GL = Grassland, WTR = Water, $\mathbf{C L}=$ Cultivated land and $\mathbf{B L T}=$ Built Up area

Table 3:- Land use/cover classification scheme

\begin{tabular}{|l|l|}
\hline Land cover class & Description \\
\hline Closed woodland & $\begin{array}{l}\text { Area of land covered low density trees forming open habitat with plenty of } \\
\text { sunlight and limited shade }\end{array}$ \\
\hline Open woodland & $\begin{array}{l}\text { Area of land covered with low density and scattered trees with crop cultivation } \\
\text { activities }\end{array}$ \\
\hline Bushland & Area dominated with bushes and shrubs \\
\hline Grassland & Land area dominated by grasses \\
\hline
\end{tabular}




\begin{tabular}{|l|l|}
\hline Water & $\begin{array}{l}\text { Area within body of land, of variable size, filled with water, localized in a } \\
\text { basin, which rivers flow into or out of them (Lake/Dam) }\end{array}$ \\
\hline Cultivated land & Farm with crops and harvested cropland \\
\hline Built up area & Man made infrastructure (roads and buildings) and settlement \\
\hline Unclassified & $\begin{array}{l}\text { Area with no input data or insufficient information which has been missed due } \\
\text { to several reason including clouds, clouds shadow, darkness, and sensor } \\
\text { dysfunctioning }\end{array}$ \\
\hline
\end{tabular}

2.2.1 Data analysis:-

To estimate amount of biomass loss of eastern Selous-Niassa TFCA from 1986 to 2016

\subsubsection{Biomass Stocks:-}

2.2.1.1.1 Living Biomass Stocks:-

Tanzania forest Carbon can be estimated in three pools namely AGB (above ground biomass), BGB (below ground biomass) and DW (dead wood) (URT, 2015). BGB was estimated as a fraction of AGB. AGB and BGB were estimated as follows:

(i) $\quad$ AGB (tonnes/ha) $=$ Tree stem volume $\left(\mathrm{m}^{3} / \mathrm{ha}\right) *$ wood density $/ 1000$; and

(ii) $\mathrm{BGB}$ (tonnes/ha) $=\mathrm{AGB} * 0.25$ (as default), or root to shoot ratios.

URT (2015) uses conversion factors into programmed NAFORMA analysis system by tree species or species groups to provide standards in each terrestrial ecosystem of Tanzania as shown in Table 4.

Table 4:- Living tree stemwood biomass by primary vegetation type

\begin{tabular}{|l|l|l|l|l|l|l|l|}
\hline Primary Vegetation Type & CWD & OWD & BS & GL & WTR & CL & BLT \\
\hline Aboveground Biomass (t/ha) & 59.5 & 27.7 & 11.0 & 2.9 & 4.6 & 5.9 & 2.9 \\
\hline Belowground Biomass (t/ha) & 18.2 & 9.5 & 4.4 & 1.1 & 1.7 & 2.1 & 1.1 \\
\hline
\end{tabular}

CWD = Closed woodland, OWD = Open woodland, BS = Bushland, GL = Grassland, WTR = Water, $\mathbf{C L}=$ Cultivated land and BLT $=$ Built Up area

\subsection{Deadwood Biomass Stocks:-}

Dead wood (DW) biomass is estimated from the volume computed using Smalian formula multiplied by wood density of $619 \mathrm{~kg} / \mathrm{m}^{3}$ (Chidumayo, 2012 cited by URT, 2015). URT (2015) through NAFORMA reveals the dead wood Biomass of Tanzania (Table 5) is relatively low since most dead wood in accessible areas is collected as fuelwood. As woodlands are generally more accessible than forests, collection of deadwood for fuelwood from these areas is easier. The relatively high volume of dead wood in water is assumed to be because dead trees lying in areas with water / wetlands are difficult to access and decay slowly and because they are wet and therefore unattractive for fuelwood.

Table 5:- Dead wood biomass by primary vegetation type

\begin{tabular}{|l|l|l|l|l|l|l|l|}
\hline Primary Vegetation Type & CWD & OWD & BS & GL & WTR & CL & BLT \\
\hline Biomass (t/ha) & 4.87 & 1.82 & 0.73 & 0.35 & 1.31 & 0.91 & 0.22 \\
\hline
\end{tabular}

CWD $=$ Closed woodland, OWD $=$ Open woodland, $\mathbf{B S}=$ Bushland, $\mathbf{G L}=$ Grassland, WTR $=$ Water, $\mathbf{C L}=$ Cultivated land and $\mathbf{B L T}=$ Built Up area

To estimate amount of carbon released to the atmosphere as a result of habitat conversion of eastern SelousNiassa TFCA from 1986 to 2016

\subsubsection{Carbon Stocks:-}

According to URT (2015), carbon in terrestrial ecosystems of Tanzania can be computed as follows:

Carbon $($ tonnes $/$ ha $)=$ Biomass $* 0.47$

Living tree stemwood and dead wood carbon (t/ha) by primary vegetation type are illustrated in Table $6 \& 7$.

Table 6:- Living tree stemwood Carbon (Aboveground + Belowground) by primary vegetation type

\begin{tabular}{|l|l|l|l|l|l|l|l|}
\hline Primary Vegetation Type & CWD & OWD & BS & GL & WTR & CL & BLT \\
\hline Carbon (t/ha) & 36.5 & 17.5 & 7.2 & 1.8 & 3.0 & 3.8 & 1.9 \\
\hline
\end{tabular}


CWD = Closed woodland, OWD = Open woodland, BS = Bushland, $\mathbf{G L}=$ Grassland, WTR $=$ Water, $\mathbf{C L}=$ Cultivated land and BLT $=$ Built Up area

Table 7:- Dead wood Carbon by primary vegetation type

\begin{tabular}{|l|l|l|l|l|l|l|l|}
\hline Primary Vegetation Type & CWD & OWD & BS & GL & WTR & CL & BLT \\
\hline Carbon (t/ha) & 2.39 & 0.89 & 0.36 & 0.17 & 0.64 & 0.45 & 0.11 \\
\hline
\end{tabular}

CWD = Closed woodland, OWD = Open woodland, BS = Bushland, GL = Grassland, WTR = Water, CL = Cultivated land and BLT $=$ Built Up area

To estimate amount of conservation profit disposed as a result of habitat conversion of eastern Selous-Niassa TFCA from 1986 to 2016

The study adopted from Jenkins (2014), and Lobora et al. (2017) emphasized that, the standard carbon market is US\$ 4 per ton if REDD+ is implemented; this was used to estimate amount of money lost from 1986 to 2016 as a result of habitat conversion of eastern Selous-Niassa TFCA.

\section{Results And Discussion:-}

3.1 Amount of biomass loss of eastern Selous-Niassa TFCA from 1986 to 2016:-

The results in Table 8 and Table 9 revealed that, nearly 93\% of closed woodland (forests) degraded compared to other vegetation type; followed by open woodland (45.74\%). This implies that, average amount of 128344.25 tons and 79708.99 tons of biomass (above ground + below ground + deadwood) from closed and open woodlands respectively loss annually from 1986 to 2016. This degradation rate impacts negatively to ecosystem services offered to wildlife residing or using the area for migration or adapting to climatic change. The degraded area converted to bushland, cultivated land and built up area due to increase of human population, livestock, and dependence of corridor dwellers on existing natural resources in the ecosystem for their livelihoods. Thereof, the average total annual loss of 163732.8 tons of biomass (above ground + below ground + deadwood) in all vegetation type from 1986 to 2016 experienced in eastern Selous - Niassa TCA. These results necessitated the inclusion of the area in core PA or formulating sustainable management strategy which will assure the survival of wildlife without compromising livelihoods of corridor dwellers. The existing formulation of wildlife management areas (WMAs) of Liwale (MAGINGO), Nachingwea (NDONDA) and Nanyumbu (MCHIMALU) districts relies only adjacently to core PAs of Selous, Msanjesi na Lukwika-Lumesule game reserves, and forgetting other areas which are crucial to wildlife as their living habitat and migration trails.

Table 8: Amount of living tree stemwood biomass (Aboveground + Belowground) loss of eastern Selous-Niassa TFCA from 1986 to 2016

\begin{tabular}{|l|l|l|l|l|l|}
\hline $\begin{array}{l}\text { Primary Vegetation } \\
\text { Type }\end{array}$ & $\begin{array}{l}\text { Total area } \\
\text { converted } \\
\text { (ha) }\end{array}$ & $\begin{array}{l}\text { Above ground } \\
\text { biomass loss } \\
\text { (t/ha) }\end{array}$ & $\begin{array}{l}\text { Below ground } \\
\text { biomass loss } \\
\text { (t/ha) }\end{array}$ & $\begin{array}{l}\text { Total Biomass } \\
\text { loss } \\
(\mathbf{t})\end{array}$ & $\begin{array}{l}\text { Biomass } \\
\text { loss }(\boldsymbol{\%})\end{array}$ \\
\hline Closed woodland & 137807 & 4.87 & 18.2 & 3179207.49 & 92.68 \\
\hline Open woodland & 181984 & 1.82 & 9.5 & 2060058.88 & 45.74 \\
\hline Bushland & -46563 & 0.73 & 4.4 & -238868.19 & -4.69 \\
\hline Grassland & 499 & 0.35 & 1.1 & 723.55 & 0.03 \\
\hline Water & 786 & 1.31 & 1.7 & 2365.86 & 0.14 \\
\hline Cultivated land & -268193 & 0.91 & 2.1 & -807260.93 & -33.71 \\
\hline Built up area & -6319 & 0.22 & 1.1 & -8341.08 & -0.19 \\
\hline Total & & \multicolumn{3}{|c|}{$\mathbf{4 1 8 7 8 8 5 . 5 8}$} \\
\hline
\end{tabular}

Table 9:- Amount of dead wood biomass loss of eastern Selous-Niassa TFCA from 1986 to 2016

\begin{tabular}{|l|l|l|l|l|}
\hline $\begin{array}{l}\text { Primary Vegetation } \\
\text { Type }\end{array}$ & $\begin{array}{l}\text { Total area } \\
\text { converted (ha) }\end{array}$ & $\begin{array}{l}\text { Biomass loss } \\
(\mathbf{t} / \mathbf{h a})\end{array}$ & $\begin{array}{l}\text { Total Biomass loss } \\
(\mathbf{t})\end{array}$ & $\begin{array}{l}\text { Biomass } \\
(\%)\end{array}$ \\
\hline Closed woodland & 137807 & 4.87 & 671120.1 & 92.68 \\
\hline Open woodland & 181984 & 1.82 & 331210.9 & 45.74 \\
\hline Bushland & -46563 & 0.73 & -33991 & -4.69 \\
\hline Grassland & 499 & 0.35 & 174.65 & 0.03 \\
\hline Water & 786 & 1.31 & 1029.66 & 0.14 \\
\hline Cultivated land & -268193 & -244056 & -33.71 \\
\hline
\end{tabular}




\begin{tabular}{|c|c|c|c|c|}
\hline Built up area & -6319 & 0.22 & -1390.18 & -0.19 \\
\hline Total & & & 724098.5 & 100.00 \\
\hline
\end{tabular}

3.2 Amount of Carbon released to the atmosphere as a result of habitat conversion of eastern Selous-Niassa TFCA from 1986 to 2016:-

The results in Table 10 and Table 11 revealed that, nearly 74.38\% of closed woodland (forests) released more Carbon to the atmosphere compared to other vegetation type; followed by open woodland (46.45\%). This implies that, average amount of 178643.81 tons and 111556.19 tons of Carbon (above ground + below ground + deadwood) from closed and open woodlands respectively loss annually from 1986 to 2016. This is something that we can never stay quiet; and the need to act urgently is unquestionable. Reversing releasing of Carbon to the atmosphere is a mitigation measure, but reacting now is adapting with mitigation measures which their results will be appreciated over thousands years to come. Thus, the need for sustainable utilization and management of natural resources in the area is vital. Conversely, the average total annual loss of 240176.88 tons of Carbon (above ground + below ground + deadwood) from 1986 to 2016 experienced in eastern Selous - Niassa TCA. Since, climate change is a result of increasing greenhouse gases in the atmosphere, there are must be strategies to reverse the situation. If, we decide to include the area into core PA network, we must incur cost that the corridor dwellers have to accept as a compensation for releasing the area for protection. In order to officiate the process, communities should be willingly accept the compensated cost that will be given to them or area similar to the previous one if and only if they actively participated and ensures that the benefits of protecting the area should be large compared to the cost. For Tanzania scenario, we must agree that those areas abandoned by wildlife which previously used as PAs should be recategorise by considering all species used to live in those areas have proper management plan which considered their climatic niche.

Table 10:- Amount of living tree stemwood Carbon (Aboveground + Belowground) released to the atmosphere as a result of habitat conversion of eastern Selous-Niassa TFCA from 1986 to 2016

\begin{tabular}{|l|l|l|l|l|}
\hline $\begin{array}{l}\text { Primary Vegetation } \\
\text { Type }\end{array}$ & $\begin{array}{l}\text { Total area } \\
\text { converted (ha) }\end{array}$ & $\begin{array}{l}\text { Carbon loss } \\
\text { (t/ha) }\end{array}$ & $\begin{array}{l}\text { Total Carbon loss } \\
(\mathbf{t})\end{array}$ & Share (\%) \\
\hline Closed woodland & 137807 & 36.5 & 5029955.5 & 73.4 \\
\hline Open woodland & 181984 & 17.5 & 3184720 & 46.48 \\
\hline Bushland & -46563 & 7.2 & -335253.6 & -4.89 \\
\hline Grassland & 499 & 1.8 & 898.2 & 0.03 \\
\hline Water & 786 & 3.0 & 2358 & 0.04 \\
\hline Cultivated land & -268193 & 3.8 & -1019133.4 & -14.88 \\
\hline Built up area & -6319 & 1.9 & -12006.1 & -0.18 \\
\hline Total & & & $\mathbf{6 8 5 1 5 3 8 . 6}$ & $\mathbf{1 0 0}$ \\
\hline
\end{tabular}

Table 11:- Amount of dead wood Carbon loss of eastern Selous-Niassa TFCA from 1986 to 2016

\begin{tabular}{|l|l|l|l|l|}
\hline $\begin{array}{l}\text { Primary Vegetation } \\
\text { Type }\end{array}$ & $\begin{array}{l}\text { Total area } \\
\text { converted (ha) }\end{array}$ & $\begin{array}{l}\text { Carbon loss } \\
\text { (t/ha) }\end{array}$ & $\begin{array}{l}\text { Total Carbon loss } \\
(\mathbf{t})\end{array}$ & Share (\%) \\
\hline Closed woodland & 137807 & 2.39 & 329358.73 & 93.11 \\
\hline Open woodland & 181984 & 0.89 & 161965.76 & 45.78 \\
\hline Bushland & -46563 & 0.36 & -16762.68 & -4.74 \\
\hline Grassland & 499 & 0.17 & 84.83 & 0.03 \\
\hline Water & 786 & 0.64 & 503.04 & 0.14 \\
\hline Cultivated land & -268193 & 0.45 & -120686.85 & -34.12 \\
\hline Built up area & -6319 & 0.11 & -695.09 & -0.2 \\
\hline Total & & & $\mathbf{3 5 3 7 6 7 . 7 4}$ & $\mathbf{1 0 0}$ \\
\hline
\end{tabular}

3.3 Amount of conservation profit disposed as a result of habitat conversion of eastern Selous-Niassa TFCA from 1986 to 2016:-

Results in Table 12 revealed that, eastern Selous - Niassa TFCA loss an average amount of US\$ 960707.5 of carbon sell annually from 1986 to 2016 due to degradation of the area. Closed woodland and open woodlands pioneered degradation on which they loss an annual average of 290200 tons of Carbon equivalent to US\$ 1160800 per annum from 1986 to 2016. It seems that open and closed woodlands have potential hard wood species which are regarded as commercial rewarding but environmental destructive by corridor dwellers. Also, the Government earmarked those 
commercial rewarding tree species with their prices; but administering their utilization and their market chain are questionable. Thus, we need community centered decision making which is integrated but different from PFM (Participatory Forest Management), JFM (Joint Forest Management) and WMA (Wildlife Management Areas) because they really not fully integrate targeted population and they cannot benefit individual entity in the community. Also, all these scenarios do not consider that those individuals in the community are changing in time, thus, scientific revised community members monitoring strategy and recording system is unavoidable; and emphasis of integrative participatory approach as advocated by Pimbert and Prety (1995).

Table 12:- Amount of conservation profit disposed as a result of habitat conversion of eastern Selous-Niassa TFCA from 1986 to 2016

\begin{tabular}{|l|l|l|l|}
\hline $\begin{array}{l}\text { Primary Vegetation } \\
\text { Type }\end{array}$ & Total Carbon loss (t) & $\begin{array}{l}\text { Amount of money loss } \\
(\text { US } \$)\end{array}$ & Share (\%) \\
\hline Closed woodland & 5359314 & 21437257 & 93.11 \\
\hline Open woodland & 3346686 & 13386743 & 45.75 \\
\hline Bushland & -352016 & -1408065 & -4.73 \\
\hline Grassland & 983.03 & 3932.12 & 0.04 \\
\hline Water & 2861.04 & 11444.16 & 0.15 \\
\hline Cultivated land & -1139820 & -4559281 & -34.11 \\
\hline Built up area & -12701.2 & -50804.8 & -0.21 \\
\hline Total & $\mathbf{7 2 0 5 3 0 6}$ & $\mathbf{2 8 8 2 1 2 2 5}$ & $\mathbf{1 0 0}$ \\
\hline
\end{tabular}

\section{Conclusion And Recommendations:-}

\subsection{Conclusion:-}

This study estimated amount of biomass loss and carbon released to the atmosphere as a result of habitat conversion of wildlife corridor connecting eastern Selous - Niassa TFCA from 1986 to 2016. The findings have revealed that, the study area has undergone notable biomass loss due to socio-economic activities performed by corridor dwellers. Also amount of carbon released to the atmosphere can contribute much to climate change and climate variability. The amount of conservation profit of the area seems to offset amount of benefit received by corridor dwellers from their destructive activities if adopted REDD+ strategies. The foreseeable future necessitates inclusion of the area into core PAs; however, there is a cost which the government must incur in order to safeguard the adaptation scenarios of wildlife suffered from climate change and variability in core PAs.

\subsection{Recommendations:-}

The study provides the following recommendations for sustainable management and conservation of eastern Selous - Niassa TFCA:

$\checkmark \quad$ The government and corridor dwellers should include the area in REDD+ scheme and use western paying principle scenario (i.e all vegetation species should have equal values despite of their location);

$\checkmark \quad$ For short and medium term strategies; the government and corridor dwellers should enhance the existing wildlife management areas (WMAs), participatory forests managements (PFMs) and joint forests managements (JFMs) so nearly $90 \%$ corridor to be under PAs management of different categories;

$\checkmark \quad$ The government should formulate user friendly guidelines for protection of wildlife corridors as stipulated in Tanzania Wildlife Conservation Act No. 5 of 2009;

$\checkmark$ The government in collaboration with other stakeholders should initiate cost effective and environmental friendly source of energy different from fuelwood

\section{References:-}

1. Araújo, M. B., Alagador, D., Cabeza, M., Nogués-Bravo, D. and Thuiller, W. (2011), Climate change threatens European conservation areas. Ecology Letters, 14: 484-492. doi:10.1111/j.1461-0248.2011.01610.x

2. Carroll, C., Dunk, J. R. and Moilanen, A. (2010), Optimizing Resiliency Of Reserve Networks To Climate Change: Multispecies Conservation Planning In The Pacific Northwest, USA. Global Change Biology, 16: 891904. Doi:10.1111/J.1365-2486.2009.01965.X

3. Falcy, M.R. \& Estades, C.F. (2007). Effectiveness of corridors relative to enlargement of habitat patches. Conservation Biology, 21, 1341-1346. 
4. Fordham, D. A., Akcakaya, H. R., Brook, B. W., Rodriguez, A., Alves, P. C., Civantos, E.,Trivino, M., Watts, M. J., and Araujo, M. B.(2013). Adapted conservation measures are required to save the Iberian lynx in a changing climate. Nature Climate Change 3: 899 - 903, doi:10.1038/nclimate1954

5. Heller, N.E. \& Zavaleta, E.S. (2009) Biodiversity management in the face of climate change: a review of 22 years of recommendations. Biological Conservation, 142, 14.

6. Hodgson, J.A., Thomas, C.D., Wintle, B.A., and Moilanen, A. (2009). Climate change, connectivity and conservation decision making: back to basics. Journal of Applied Ecology 46: 964-969, doi: 10.1111/j.13652664.2009.01695.x

7. Jenkins, C.N., and Joppa, L. (2009). Expansion of the global terrestrial protected area system. Biological Conservation, 142 (10), 2166-2174. doi:10.1016/j.biocon.2009.04.016

8. Li, R. Q., Dong, M., Cui, J. Y., Zhang, L. L., Cui, Q. G. and He, W. M., (2007). Quantification of the impact of land-use changes on ecosystem services: a case study in Pingbian County, China. Environmental Monitoring and Assessment 128(3): 503 - 510.

9. Lobora, A., Nahonyo, C., Munishi, L., Caro, T., Foley, C., and Beale, C. (2017): Modelling habitat conversion in miombo woodlands: insights from Tanzania, Journal of Land Use Science, DOI: 10.1080/1747423X.2017.1331271

10. Milad, M., Schaicha, H., Burgib, M., Konolda, W., (2011). Climate change and nature conservation in Central European forests: A review of consequences, concepts and challenges. Forest Ecology and Management 261: 829-843.

11. Munishi, P.K.T., Mringi, S., Shirima, D.D., \& Linda, S.K. (2010). The role of the Miombo Woodlands of the Southern Highlands of Tanzania as carbon sinks. Journal of Ecology and the Natural Environment, 2(12), 261269. http://www.academicjournals.org/jene

12. Ntongani, W.A., Munishi, P.K.T. and Mbilinyi, B.P. (2007). Land use/cover change and socio-economic factors influencing land cover dynamics in the Selous-Niassa wildlife corridor Nachingwea District Tanzania. Proceedings of the sixth TAWIRI scientific conference. Dec, 2007.

13. Pesambili, A. (2003). Wildlife resources of Lukwika-Lumesule and Msanjesi Game Reserves. WWF-TPO. 12pp.

14. Pimbert, F. and Pretty, J.N (1995). People, Professionals and Conservation, UNSIID, Geneva.

15. Pressey, R.L., Cabeza, M., Watts, M.E., Cowling, R.M. \& Wilson, K.A. (2007). Conservation planning in a changing world. Trends in Ecology \& Evolution, 22, 583-592.

16. Rayfield, B., James, P.M.A., Fall, A., and Fortin, M. (2008) Comparing static versus dynamic protected areas in the Québec boreal forest. Biolpgical Conservation 141: $438 \quad-\quad 499$, https://doi.org/10.1016/j.biocon.2007.10.013

17. Schulp, C.J.E., Nabuurs, G._J., Verburg, P.H., (2008). Future Carbon Sequestration in Europe - Effects of Land Use Change. Agriculture, Ecosystems and Environment, 127: 251 - 264.

18. Shao, J., J., Wei Ch., Xie D., (2005). Land Use Change and Its Corresponding Ecological Responses: A Review. Journal of Geographical Sciences 15(3): 305-328.

19. Stohlgren, T. J., Binkley, D., Chong, G. W., Kalkhan, M. A., Schell, L. D., Bull, K. A., Otsuki, Y., Newman, G., Bashkin, M. and Son, Y. (1999), Exotic Plant Species Invade Hot Spots Of Native Plant Diversity. Ecological Monographs, 69: 25-46. doi:10.1890/0012-9615(1999)069[0025:EPSIHS]2.0.CO;2

20. Strange A, Li P, Lister C, Anderson J, Warthmann N, Shindo C, et al. (2011) Major-Effect Alleles at Relatively Few Loci Underlie Distinct Vernalization and Flowering Variation in Arabidopsis Accessions. PLoS ONE 6(5): e19949. https://doi.org/10.1371/journal.pone.0019949

21. United Republic of Tanzania (URT), (2015). National Forest Resources Monitoring and Assessment of Tanzania Mainland. Ministry of Natural Resources and Tourism, Dar es Salaam.

22. Williams, P., Hannah, L., Andelman, S., Midgley, G., Araújo, M., Hughes, G., Manne, L., Martinez-Meyer, E. and Pearson, R. (2005), Planning for Climate Change: Identifying Minimum-Dispersal Corridors for the Cape Proteaceae. Conservation Biology, 19: 1063-1074. doi:10.1111/j.1523-1739.2005.00080.x

23. World Bank. 2010. World Development Report 2010 : Development and Climate Change. Washington, DC. (C) World Bank. https://openknowledge.worldbank.org/handle/10986/4387 License: CC BY 3.0 IGO 